\title{
Geoengineering in lakes: welcome attraction or fatal distraction?
}

Eleanor B. Mackay ${ }^{1}$, Stephen C. Maberly ${ }^{1}$, Gang Pan², Kasper Reitzel ${ }^{3}$, Andy Bruere ${ }^{4}$, Nicholas Corker ${ }^{5}$, Grant Douglas $^{6}$, Sara Egemose ${ }^{3}$, David Hamilton ${ }^{7}$, Tristan Hatton-Ellis ${ }^{8}$, Brian Huser ${ }^{9}$, Wei Li $^{10}$, Sebastian Meis ${ }^{11}$, Brian Moss ${ }^{12}$, Miquel Lürling ${ }^{13}$, Geoff Phillips ${ }^{14}$, Said Yasseri ${ }^{15}$, and Bryan M. Spears ${ }^{16 *}$

${ }^{1}$ Centre for Ecology \& Hydrology, Lancaster Environment Centre, Bailrigg, Lancaster, United Kingdom

${ }^{2}$ Research Center for Eco-Environmental Sciences, The Chinese Academy of Sciences, Haidian District, Beijing, China

${ }^{3}$ Department of Biology, University of Southern Denmark, Odense M, Denmark

${ }^{4}$ Bay of Plenty Regional Council, Rotorua, New Zealand

${ }^{5}$ Centre for Ecology \& Hydrology, Wallingford, Oxfordshire, United Kingdom

${ }^{6}$ CSIRO Land and Water, Wembley, Australia

${ }^{7}$ Environmental Research Institute, University of Waikato, New Zealand

${ }^{8}$ Natural Resources Wales, Bangor, Gwynedd, United Kingdom

${ }^{9}$ Swedish University of Agricultural Sciences, Department of Aquatic Sciences and Assessment, Uppsala, Sweden

${ }^{10}$ Wuhan Botanical Garden, Chinese Academy of Science, Moshan, Wuhan, P.R. China

${ }^{11}$ Lanaplan GbR, Nettetal, Germany

${ }_{12}$ School of Environmental Sciences, University of Liverpool, United Kingdom

${ }^{13}$ Water Quality Management Group, Department of Environmental Sciences, Wageningen University, Wageningen, The Netherlands

${ }^{14}$ Environment Agency, Reading, United Kingdom

${ }^{15}$ Institut Dr. Nowak, Ottersberg, Germany

${ }^{16}$ Centre for Ecology \& Hydrology, Penicuik, Midlothian, United Kingdom

*Corresponding author: spear@ceh.ac.uk

Received 2 June 2014; accepted 1 July 2014; published 5 August 2014

\section{Abstract}

The use of geoengineering techniques for phosphorus management offers the promise of greater and quicker chemical and ecological recovery. It can be attractive when used with other restoration measures but should not be considered a panacea. The range of materials being proposed for use as well as the in-lake processes targeted for manipulation continues to grow. With increasing political imperatives to meet regulatory goals for water quality, we recommend a coordinated approach to the scientific understanding, costs, and integration of geoengineering with other approaches to lake management.

Key words: capping, management, phosphorus inactivation, restoration

\section{Introduction}

Lakes are vulnerable to human impacts because of the links to their catchments and the sensitivity of biotic communities to changes in hydrology, water chemistry, and morphometry. As well as being globally important habitats, lakes provide ecosystem services such as water supply, recreation, commercial fisheries, angling, conservation, and amenity, many of which have long been under pressure from changes in both the catchments and the lakes themselves. Lakes, and the freshwater system in general, are also important in the maintenance and regulation of global biogeochemical cycles (e.g., carbon, nitrogen), and local human impacts may collectively have implications on a wider scale.

A range of pressures, competing requirements, and the complexity of these systems complicate the management of lakes. First, improving lake quality to retain or restore lake ecosystem services to achieve local goals, especially in amenity, conservation, and angling, may differ from the 
greater goals of meeting national and regional policy requirements (van der Veeren and Lorenz 2002). Second, targets for improvement reflect the time scales of the public, government, and administrators, while ecological problems and their solutions often operate over longer periods. Third, there is an inherent tension between food production and economic activity in the catchment and ecological quality in downstream waters. Finally, catchments and their freshwater systems are complicated and, in some cases, scientific evidence to support the most effective course of action is unclear.

An attractive solution to these problems is the use of geoengineering, defined here as the deliberate manipulation of lake processes using natural and engineered amendments to induce a desired chemical or ecological outcome. It offers the promise of rapid effects, although the wisdom of its use in isolation is questionable. Given the deadlines imposed by environmental legislation for improving water resources, such measures have received increasing attention, resulting in a growing "green industry"; however, the approach is contentious, being criticised by some as a distraction when better understanding of the management of extrinsic pressures on lakes is most critical.

Using a set of simple questions, we highlight the conflicts and points of consensus on the use of geoengineering in lake management and propose that use of geoengineering should be considered as part of a package of measures following the high-level principles set by the Convention on Biological Diversity (Secretariat of the Convention on Biological Diversity 2004) as well as following the guidance of the United Nations Environment Programme (UNEP) on Water Quality for Ecosystem and Human Health (UNEP 2007).

\section{What does geoengineering do?}

The premise of geoengineering in lakes is to manipulate biogeochemical processes known to improve ecological structure and function. It most commonly focuses on the rapid reduction of phosphorus concentrations in the water column, leading to reduction of phytoplankton biomass. In shallow lakes, the approach is being tested as a means to force a change in ecological state from a phytoplanktondominated, turbid state to a clear-water, plant-dominated state through disruption of internal loading (Fig. 1). In deeper lakes, where stratification occurs, materials can be injected into the hypolimnion to target dissolved phosphorus released from sediments but contained in bottom waters by the thermocline.

Materials are commonly applied to the inflows, surface waters, bottom waters, or sediments using a range of slurry injection and spraying equipment. When added to the water column, the materials strip out dissolved phosphorus as they sink to the bed sediments, where they may continue to act to reduce diffusion of dissolved phosphorus from the lake bed to the water column (e.g., Robb et al. 2003, Reitzel et al. 2005, Pan et al. 2006, 2012a, Meis et al. 2012). The range of products used is growing and includes engineered materials, commercially available salts, modified local soils, and industrial by-products (Hickey and Gibbs 2009). Substances are also currently being developed to flocculate phytoplankton; modify dissolved oxygen, carbon, and nitrogen concentrations; and to encourage spread of desirable plants through propagule dispersal (Pan et al. 2011a, 2011b, van de Weyer et al. 2014). Manipulation of benthic bacterial communities through increasing redox status, using materials capable of delivering oxygen microbubbles, has also been used (Pan et al. 2012b). Perhaps the most widespread use of the approach, however, has been the liming of lakes to reduce the effects of acidification (Guhrén et al. 2007, Angelar and Goedkoop 2010).

The global market for geoengineering materials is difficult to define because published data on the number and size of treated lakes and ponds are limited. With respect to phosphorus inactivation, however, about 50 lakes have been treated with aluminium-based compounds in the United States over the last 5 years (B. Huser, pers. comm.), while in 2013, Phoslock, a lanthanum-modified bentonite clay product, was added to at least 30 lakes across the world (S. Yaseri, pers. comm.), and modified local soil materials were used in several waterbodies in China (G. Pan, pers. comm.).

\section{Why is the approach attractive?}

Interest in the use of geoengineering in lakes is increasing, partly owing to looming deadlines of several environmental policies. In Europe, the European Union (EU) Water Framework Directive (WFD) has made achieving environmental objectives (by default "good status") for waterbodies by 2027 a legal requirement. In addition, the EU Bathing Waters Directive calls for "real-time" targets to meet public health standards associated with potentially toxic cyanobacteria. There are similar intentions on other continents.

These tasks are challenging, and so are estimates for the cost of meeting them using geoengineering (Fig. 2). In addition to the WFD, the EU Biodiversity Strategy includes targets to halt deterioration and achieve a significant improvement in habitats and species covered by the Habitats and Birds Directives by 2020 (European Commission 2011). The Chinese government is planning a national "10 target water program" ( $€ 240$ million) to improve water quality by 2020 . In addition, under section 


\section{ALGAL DOMINATED STATE}

Resilience to change maintained through high algal production and internal $P$ cycling

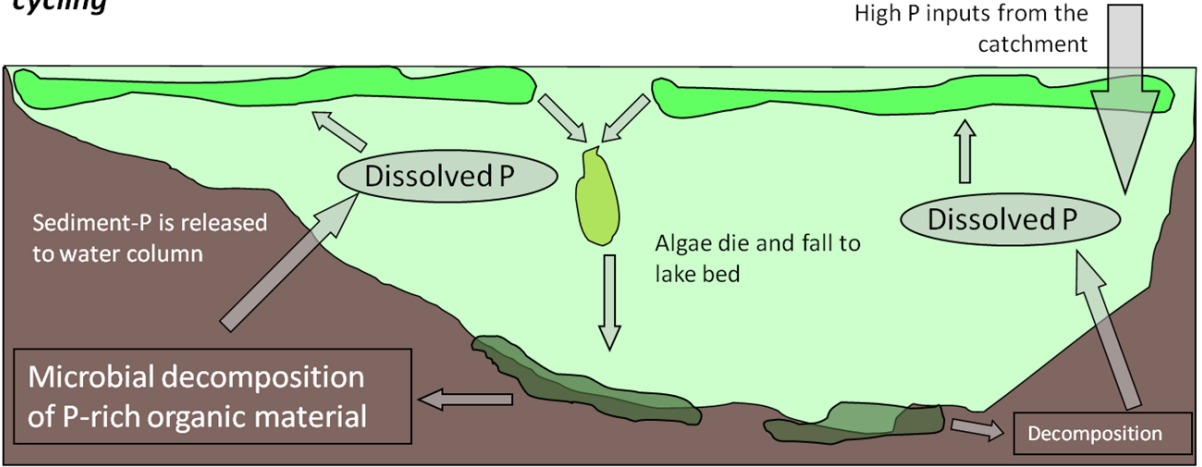

\section{FORCING A CHANGE OF STATE}

Following successful reduction of catchment $P$ inputs, internal loading feedback mechanism is disrupted using geo-engineering products providing an opportunity for aquatic macrophytes to re-establish lake bed sediments

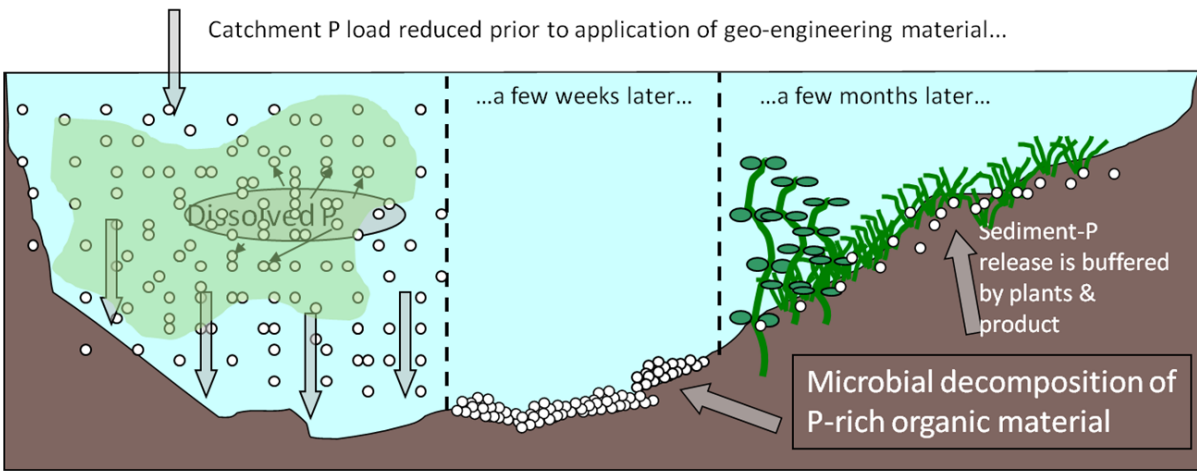

\section{PLANT DOMINATED STATE}

\section{Resilience to change maintained through high plant production and regulation of} internal $P$ cycling

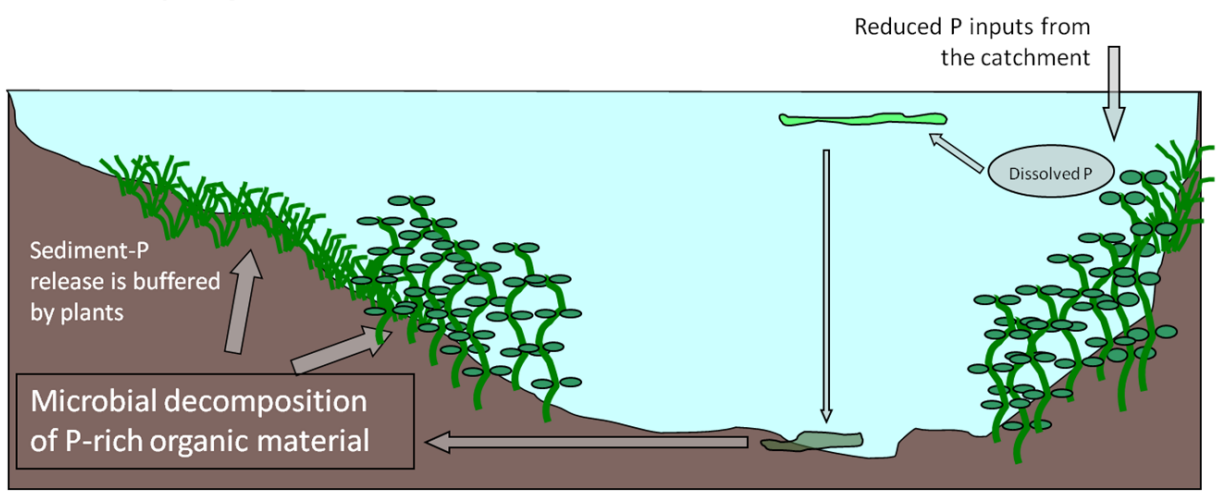

$$
[P=\text { phosphorus }]
$$

Fig. 1. Alternative stable states in shallow lakes and action of geoengineering products to disrupt stabilising feedback mechanisms. 
303d of the Clean Water Act, US states are required to "list" impaired water bodies and develop maximum allowable pollutant limits (e.g., phosphorus) to safely meet water quality standards (Clean Water Act of 1972). Pressure from these policies is likely to increase the impetus for improvements in lake systems over the next decade, although the likelihood of success is still debatable (Moss 2008, Hering et al. 2010). In addition, the European Commission is encouraging the creation of new technologies through a pilot scheme designed to accelerate market entry (the EU Environmental Technology Verification Scheme). This scheme provides verified evidence that innovative environmental technologies are credible, scientifically sound, and perform as they claim.

Geoengineering promises quick results (days to years) compared with the recovery times from reduction of catchment nutrient load alone (years to decades; Jarvie et al. 2013). It targets the internal nutrient source, which reflects the historical pollution received by the lake, and is the main driver behind self-perpetuating poor water quality conditions following catchment management. The approach appears relatively straightforward, where the necessary dose is calculated from "available phosphorus" pools in the sediment and the water column. Although significant advances have been made in dose estimation and product application in recent years (e.g., for aluminium; Huser and Pilgrim 2014), significant uncertainty still remains (Meis et al. 2013, Hamilton et al. 2014).
Experimental treatments with these materials, both in situ and in the laboratory, may help in understanding lake processes, in particular, measuring ecological resilience to environmental change in lakes (Carpenter and Cottingham 1997, Batt et al. 2013, Carpenter et al. 2014). Ecological responses caused by geoengineering may provide insight into the feedback mechanisms that maintain shallow lakes in their turbid, phytoplankton-dominated state or clear, macrophyte-dominated state (Scheffer et al. 1993, Mehner et al. 2008).

\section{What are the problems and risks associated with the use of geoengineering?}

"Quick fix" environmental management is not new, with many examples of both successes and failures being reported in the literature (Sterner et al. 2006). In addition, "goal oriented" management is short-sighted, such as that focussing solely on achieving phosphorus reductions alone by arbitrary deadlines, with little consideration of socioecological responses. Geoengineering risks being viewed as a "silver bullet" to rapidly solve water quality problems in lakes and to achieve legal compliance without proper consideration of whether sustained ecological improvements can be achieved. Geoengineering should not be viewed as a solution in isolation or a panacea for eutrophication problems. Rather it is a tool that can be used with other approaches (Robertson et al. 2000) but
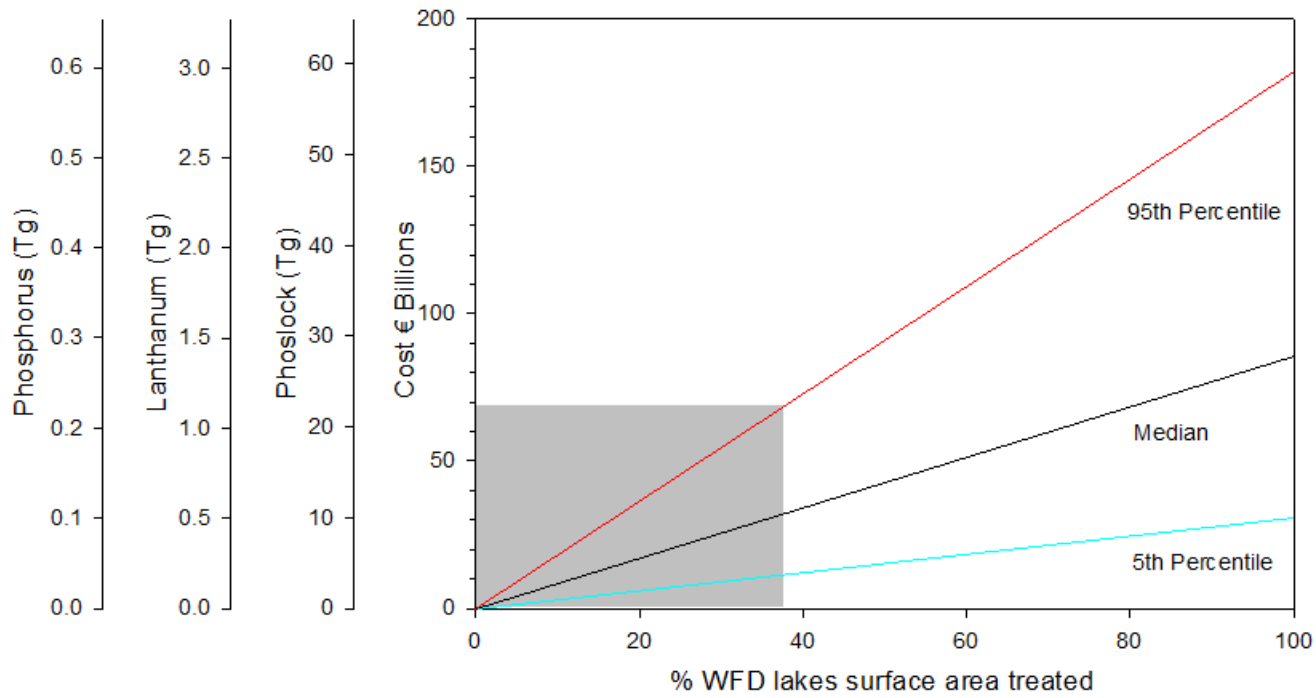

Fig. 2. The impact of using geoengineering to facilitate water quality improvements at the EU scale, where $38 \%$ of lakes fail water quality targets (indicated by grey box). Plot is based on costs reported by Spears et al. (2013b) for use of Phoslock. All data for EU WFD were extracted from http://www.eea.europa.eu/data-and-maps/data/wise_wfd. This hypothetical analysis assumes that (1) all failing lakes require phosphorus reduction; (2) the cost of Phoslock is consistent (at €2750 per tonne) across countries; (3) that $100 \mathrm{~kg}$ of Phoslock will bind $1 \mathrm{~kg}$ of phosphorus; and (4) that Phoslock is composed of $5 \%$ lanthanum by weight. Estimates of aerial Phoslock load $\left(5^{\text {th }}, 50^{\text {th }}\right.$ and $95^{\text {th }}$ percentiles displayed) taken from data from 16 case study lakes (Spears et al. 2013c). 
should be carefully designed for the specific conditions in each lake and its catchment. Unless external nutrient sources and other contributing problems in the receiving waters are adequately managed and local communities are involved in decision-making, geoengineering techniques will deliver only transient benefits without repeat treatments (Egemose et al. 2011). The cost of such maintenance management should be assessed against the cost of doing nothing; for example, the cost of closure of a site of high recreational value may be greater than the cost to implement geoengineering techniques to reduce human health risk associated with cyanobacteria.

It is critical that the materials proposed be used correctly and applied only to target lakes that are likely to respond to treatment (Spears et al. 2013a). In-lake factors including water chemistry are known to limit the phosphorus-binding capacity of geoengineering materials and may limit applicability in some lakes (de Vicente et al. 2008, Douglas et al. 2012, Reitzel et al. 2013a, 2013b, 2013c, Lürling et al. 2014). With continued external loading and sedimentation, capping products are likely to become buried beneath fresh, nutrient-rich sediment, reducing their efficiency, or binding sites for nutrients may become saturated, leading to persistent nutrient release into the overlying water column (Lewandowski et al. 2003, Gibbs et al. 2010).

Unintended or unforeseen consequences may be associated with the approach, which can be viewed as either positive or negative with respect to the desired ecological outcomes. At the sediment-water interface, higher oxygen concentrations and reduced ammonification can lead to reduced concentrations of ammonium in the water column (Vopel et al. 2008, Egemose et al. 2011). Phosphorus removal may also cause a shift from nitrogen-limited to phosphorus-limited growth of phytoplankton, resulting in higher concentrations of in-lake nitrate (Egemose et al. 2011, Wendling et al. 2013).

Such alterations of biogeochemical cycles could affect greenhouse gas emissions from lakes, for example, by altering the balance of methane or carbon dioxide production or through reductions in denitrification rates leading to reduced nitrous oxide and nitrogen gas production. Materials (including gypsum) have been proposed to limit such emissions from lakes (Varjo et al. 2003).

Changes to greenhouse gas emissions may also be expected following eutrophication management utilising catchment management alone, albeit over longer time scales (Finlay et al. 2013). Other potentially negative effects associated with the application of geoengineering materials include the increased risk of ecotoxicological effects caused by chemical components of the materials used, increases and decreases in water column $\mathrm{pH}$, increased turbidity and decreased potability, and increased risk of invasion by nonendemic macrophyte species (Hickey and Gibbs 2009, Gunn et al. 2013, Spears et al. 2013c).

\section{Is there a socioeconomic drive for geoengineering?}

A better understanding of the costs of achieving policy goals such as those in the WFD is needed to assess the cost-effectiveness of large-scale geoengineering programmes. Little information has been provided to the EU from member states on the costs associated with implementing River Basin Management Plans (Tucker et al. 2013). Where costs do exist, they are often uncertain, not linked to estimates of effectiveness, are difficult to compare between countries, or do not specify the extent of measures included (Hart et al. 2011, European Commission 2012). Costs of implementing the Urban Waste Water Treatment Directive (which preceded the WFD and concerned improvements in sewage disposal, including nutrient removal) are not well known (COWI 2010). The estimated costs for use of geoengineering materials in the EU range from $€ 0.3$ million to $€ 0.8$ million $\mathrm{km}^{-2}$ (cost estimates provided by manufacturers; Spears et al. 2013b) and could mean substantial investment for some EU member states (Fig. 2).

Costs reported in the literature from various case studies are variable (reviewed by Hamilton et al. 2014). Vinten et al. (2012) presented a cost analysis for Scottish lochs to meet WFD targets assuming phosphorus management. The cost of using Phoslock was relatively high (about $€ 200 \mathrm{~kg}^{-1}$ phosphorus removed) compared with catchment measures (e.g., about $€ 15 \mathrm{~kg}^{-1}$ for phosphorus removed from sewage treatment works and about $€ 35 \mathrm{~kg}^{-1}$ for phosphorus removed from septic tanks). The targeted phosphorus reduction in the sewage works relates to historic in-lake nutrients and is therefore theoretically needed only once, while septic tanks concern current catchment inputs and will be needed for the duration of the pressure, irrespective of the use of precipitants in the lake. A product application cost of $€ 0.8$ million $\mathrm{km}^{-2}$ loch surface area (Spears et al. 2013b) would mean about $€ 80$ million to treat all $105 \mathrm{~km}^{2}$ of Scottish lochs currently failing WFD total phosphorus standards (Vinten et al. 2012).

A further issue is the public perception of geoengineering. The costs, the addition of chemicals to manipulate the natural environment, and the unpredictability of the results will all contribute to informing public attitudes. Discussions are needed among scientists, the public, regulators, and policy makers to better communicate the uncertainties and experimental nature of lake restoration 
projects utilising relatively novel management approaches (Phillips et al. 1999, Moss et al. 2002). Failure to do so could result in loss of public trust in the science of lake management and the case for pursuing restoration, analogous to the current mismatch between public perceptions on the existence and causes of climate change versus the strong scientific consensus (Cook et al. 2013, Poortinga et al. 2013). Appropriate engagement with all those interested in a particular lake where measures are proposed is vital.

\section{Conclusion}

Substantial uncertainties remain with the use of geoengineering in lakes in terms of scientific understanding, costs, and integration with other lake management measures. Given careful management of these risks, however, the approach may allow improvements, for example, where phosphorus stores strongly hinder the effectiveness of nutrient management focused only on the catchment. More time is needed to produce scientific evidence to underpin wide-scale use of the approach; however, policy and political programmes are operating on ambitiously short time scales. Consensus within the scientific community on the levels of confidence in the approach required to support wide-scale use remains elusive, and open debate on this issue is critical. The issue of scientific consensus and the need for open debate could also be argued for many other lake restoration measures.

Uncertainties, unintended consequences, and the costs of treatment mean that the use of geoengineering, along with other management measures, should be considered within a broader context of catchment management and public consultation. At present, although the approach is routinely used across some countries, others would benefit if standard, theory-driven experimental protocols could be implemented in future applications. Standardised protocols would aid comparability of data to facilitate meta-analyses. The potential to test scientific theory at the field scale using these tools is clear. Every new case study contributes new insights into lake structure and function, which underpin our ability to restore impacted lakes and increase the provision of desirable services.

\section{References}

Angelar D, Goedkoop W. 2010. Biological responses to liming in boreal lakes: an assessment using plankton, macroinvertebrates and fish communities. J Applied Ecol. 47:478-486.

Batt RD, Carpenter SR, Cole JJ, Pace ML, Johnson RA. 2013. Changes in ecosystem resilience detected in automated measures of ecosystem metabolism during a whole-lake manipulation. P Natl Acad Sci USA. 110:17398-17403.
Carpenter SR, Brock WA, Cole JJ, Pace ML. 2014. A new approach for rapid detection of nearby thresholds in ecosystem time series. Oikos. 123:290-297.

Carpenter SR, Cottingham KL. 1997. Resilience and restoration of lakes. Conserv Ecol [online]; 1:2. Available from: http://www. consecol.org/vol1/iss1/art2/

Clean Water Act of 1972. 2002. 33 U.S.C. § 1251 et seq. Available from: http://epw.senate.gov/water.pdf

Cook J, Nuccitelli D, Green S, Richardson M, Winkler B, Painting R, Way R, Jacobs P, Skuce A. 2013. Quantifying the consensus on anthropogenic global warming in the scientific literature. Environ Res Lett. doi:10.1088/1748-9326/8/2/024024

COWI. 2010. Compliance costs of the Urban Wastewater Treatment Directive final report. Brussels (Belgium).

De Vicente I, Huang P, Andersen FØ, Jensen HS. 2008. Phosphate adsorption by fresh and aged aluminum hydroxide: consequences for lake restoration. Environ Sci Technol. 42:6650-6655.

Douglas GB, Adeney JA, Johnston K, Wendling LA, Coleman S. 2012. Investigation of major, trace element, nutrient and radionuclide mobility in a mining by-product (NUA)-amended soil. J Environ Qual. 41:1818-1834.

Egemose S, Vicente I De, Reitzel K, Flindt MR, Andersen FØ, Lauridsen TL, Søndergaard M, Jeppesen E, Jensen HS. 2011. Changed cycling of P, N , Si , and DOC in Danish Lake Nordborg after aluminum treatment. Can J Fish Aquat Sci. 68:842-856.

European Commission. 2011. Our life insurance, our natural capital: an EU biodiversity strategy to $2020 \operatorname{COM}(2011) 244$ final. Brussels (Belgium).

European Commission. 2012. Report from the Commission to the European Parliament and the Council on the implementation of the Water Framework Directive (2000/60/EC) River Basin Management Plans COM(2012) 670 final. Brussels (Belgium).

Finlay JC, Small GE, Sterner RW. 2013. Human influences on nitrogen removal in lakes. Science. 342:247-250.

Gibbs MM, Hickey CW, Özkundakci D. 2010. Sustainability assessment and comparison of efficacy of four P-inactivation agents for managing internal phosphorus loads in lakes: sediment incubations. Hydrobiologia. 658:253-275.

Guhrén M, Bigler C, Renberg I. 2007. Liming placed in a long-term perspective: a paleolimnological study of 12 lakes in the Swedish liming program. J Paleolimnol. 37(2):247-258.

Gunn IDM, Meis S, Maberly SC, Spears BM. 2013. Assessing the responses of aquatic macrophytes to the application of a lanthanum modified bentonite clay, at Loch Flemington, Scotland, UK. Hydrobiologia. doi:10.1007/s10750-013-1765-5

Hamilton DP, Wood SA, Dietrich DR, Puddick J. 2014. Costs of harmful blooms of freshwater cyanobacteria. In: Sharma NV, Rai AK, Stal LJ, editors. Cyanobacteria: an economic perspective. John Wiley \& Sons. p. 247-256.

Hart K, Baldock D, Tucker G, Allen B, Calatrava J, Black H, Newman S, Baulcomb C, McCracken D GS. 2011. Costing the environmental needs related to rural land management final report. London (UK). 
Hering D, Borja A, Carstensen J, Carvalho L, Elliott M, Feld CK, Heiskanen A-S, Johnson RK, Moe J, Pont D, et al. 2010. The European Water Framework Directive at the age of 10: a critical review of the achievements with recommendations for the future. Sci Total Environ. 408:4007-4019.

Hickey CW, Gibbs MM. 2009. Lake sediment phosphorus release management: decision support and risk assessment framework. New Zeal J Mar Freshw Res. 43:819-856.

Huser BJ, Pilgrim KM. 2014. A simple model for predicting alumnimum bound phosphrous formation and internal loading reduction in lakes after aluminum addition to lake sediment. Water Res. 53:378-385.

Jarvie HP, Sharpley AN, Spears B, Buda AR, May L, Kleinman PJA. 2013. Water quality remediation faces unprecedented challenges from "legacy phosphorus." Environ Sci Technol. 47:8997-8998.

Lewandowski J, Schauser I, Hupfer M. 2003. Long-term effects of phosphorus precipitations with alum in hypereutrophic Lake Süsser See (Germany). Water Res. 37:3194-204.

Lürling M, Waajen G, van Oosterhout F. 2014. Humic substances interfere with phosphate removal by lanthanum modified clay in controlling eutrophication. Water Res. 54:78-88.

Mehner T, Diekmann M, Gonsiorczyk T, Kasprzak P, Koschel R, Krienitz L, Rumpf M, Schulz M, Wauer G. 2008. Rapid recovery from eutrophication of a stratified lake by disruption of internal nutrient load. Ecosystems. 11:1142-1156.

Meis S, Spears BM, Maberly SC, O’Malley MB, Perkins R. 2012. Sediment amendment with Phoslock $\AA$ in Clatto Reservoir (Dundee, UK): investigating changes in sediment elemental composition and phosphorus fractions. J Environ Monit. 93:185-193.

Meis S, Spears BM, Maberly SC, Perkins R. 2013. Assessing the

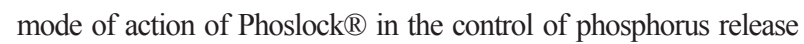
from the bed sediments in a shallow lake (Loch Flemington, UK). Water Res. 47:4460-4473.

Moss B. 2008. The Water Framework Directive: total environment or political compromise? Sci Total Environ. 400:32-41.

Moss B, Carvalho L, Plewes J. 2002. The lake at Llandrindod Wells - a restoration comedy? Aquat Conserv. 12:229-245.

Pan G, Chen J, Anderson D. 2011a. Modified local sands for the mitigation of harmful algal blooms. Harmful Algae. 10:381-387.

Pan G, Dai L, Li L, Shang Y, Li H, Bi L, He L, Wang L, Wang D, Li Q, Li L, Gu X, Zhong J, Yu Y, Yan Q. 2012a. Eutrophication control using modified local soil/sand induced ecological restoration technology: I. Effect and mechanism on short and long term improvement of water quality. J Lake Sci. 24(6):801-810.

Pan G, Dai L, Li L, He L, Li H, Bi L, Gulati RD. 2012b. Reducing the recruitment of sedimented algae and nutrient release into the overlying water using modified soil/sand flocculation-capping in eutrophic lake. Environ Sci Technol. 46:5077-5084.

Pan G, Yang B, Wang D, Chen H, Tian B, Zhang M, Yuan X, Chen J. 2011b. In-lake algal bloom removal and submerged vegetation restoration using modified local soils. Ecol Eng. 37:302-308.

Pan G, Zou H, Chen H, Yuan X. 2006. Removal of harmful cyanobacterial blooms in Taihu Lake using local soils. III. Factors affecting the removal efficiency and an in situ field experiment using chitosan-modified local soils. Environ Pollut. 141:206-212.

Phillips G, Bramwell A, Pitt J, Stansfield J, Perrow M. 1999. Practical application of 25 years research into the management of shallow lakes. Hydrobiologia. 395/396:61-76.

Poortinga W, Pidgeon NF, Capstick S, Aoyagi M. 2013. Public attitudes to nuclear power and climate change in Britain two years after the Fukushima accident. Cardiff(UK).

Reitzel K, Andersen FØ, Egemose S, Jensen HS. 2013a. Phosphate adsorption by lanthanum modified bentonite clay in fresh and brackish water. Water Res. 47:2787-2796.

Reitzel K, Hansen J, Andersen FØ, Hansen KS, Jensen HS. 2005. Lake restoration by dosing aluminum relative to mobile phosphorus in the sediment. Environ Sci Technol. 39:4134-4140.

Reitzel K, Jensen HS, Egemose S. 2013b. pH dependent dissolution of sediment aluminum in six Danish lakes treated with aluminum. Water Res. 47:1409-1420.

Reitzel K, Lotter S, Dubke M, Egemose S, Jensen HS, Andersen FØ. 2013c. Effects of Phoslock treatment and chironomids on the exchange of nutrients between sediment and water. Hydrobiologia. 703:189-202.

Robb M, Greenop B, Goss Z, Douglas G. Adeney J. 2003. Application of Phoslock ${ }^{\mathrm{TM}}$, an innovative phosphorus binding clay, to two Western Australian waterways - preliminary findings. Hydrol Process. 494:237-243.

Robertson DM, Goddard GL, Helsel DR, MacKinnon KL. 2000. Rehabilitation of Delavan Lake, Wisconsin. Lake Res Manage. 16:155-176.

Scheffer M, Hosper SH, Meijer M-L, Moss B, Jeppesen E. 1993. Alternative equilibria in shallow lakes. Trends Ecol Evol. 8:275-279.

Secretariat of the Convention on Biological Diversity. 2004. The Ecosystem Approach. Montreal (Canada).

Spears BM, Meis S, Anderson A, Kellou M. 2013a. Comparison of phosphorus $(\mathrm{P})$ removal properties of materials proposed for the control of sediment $\mathrm{P}$ release in UK lakes. Sci Total Environ. 442:103-110.

Spears BM, Dudley B, Reitzel K, Rydin E. 2013b. Geo-Engineering in Lakes: a call for consensus. Environ Sci Technol. 47:3953-3954.

Spears BM, Lürling M, Yasseri S, Castro-Castellon AT, Gibbs M, Meis S, McDonald C, McIntosh J, Sleep D, Van Oosterhout F. 2013c. Lake responses following lanthanum-modified bentonite clay (Phoslock $($ ) application: an analysis of water column lanthanum data from 16 case study lakes. Water Res. 47:59305942.

Sterner BT, Troell M, Vincent J, Aniyar S, Barrett S, Brock W, Carpenter S, Chopra K, Ehrlich P, Hoel M, et al. 2006. Quick fixes for the environment. Part of the solution or part of the problem? Environment. 48:20-27.

Tucker G, Underwood E, Farmer A, Scalera R, Dickie I, McConville A, van Vliet W. 2013. Estimation of the financing needs to implement Target 2 of the EU Biodiversity Strategy. Report to the European Commission. London (UK). 
[UNEP] United Nations Environmental Programme. 2007. Water quality for ecosystem and human health, 2nd ed. Prepared and published by the United Nations Environment Programme Global Environment Monitoring System (GEMS)/Water Programme. ISBN 92-95039-51-7.

van der Veeren RJHM, Lorenz CM. 2002. Integrated economic-ecological analysis and evaluation of management strategies on nutrient abatement in the Rhine basin. J Environ Manage. 66:361-376.

Van de Weyer K, Sümer G, Hueppe H, Petruck A. 2014. Das Konzept PHOENIX See: Nachhaltiges management von makrophytenmassenentwicklungen durch eine kombination nährstoffarmer standortbedingungen und bepflanzung mit armleuchteralgen. Korrespondenz Wasserwirtschaft. 7:23-27.
Varjo E, Kiikanen A, Salonen VP, Martikainen PJ. 2003. A new gypsum-based technique to reduce methane and phosphorus release from sediments of eutrophied lakes. Water Res. 37:1-10.

Vinten AJA, Martin-Ortega J, Glenk K, Booth P, Blanda BB, Macleod M, Lago M, Moran D, Jones M. 2012. Application of the WFD cost proportionality principle to diffuse pollution mitigation: a case study for Scottish lochs. J Environ Manage. 97:28-37.

Vopel K, Gibbs MM, Hickey CW, Quinn J. 2008. Modification of sediment-water solute exchange by sediment-capping materials: effects on $\mathrm{O}_{2}$ and $\mathrm{pH}$. Mar Freshw Res. 59:1101-1110.

Wendling L, Douglas G, Coleman S, Yuan Z. 2013. Nutrient and dissolved organic carbon removal from natural waters using industrial by-products. Sci Total Environ. 442:63-72. 